9-14-2018

\title{
The Ovicaprine Mystique: Livestock Commodification in Postindustrial Lesotho
}

\author{
Colin Hoag \\ Smith College,choag@smith.edu
}

Follow this and additional works at: https://scholarworks.smith.edu/ant_facpubs

Part of the Anthropology Commons

\section{Recommended Citation}

Hoag, Colin, "The Ovicaprine Mystique: Livestock Commodification in Postindustrial Lesotho" (2018). Anthropology: Faculty Publications, Smith College, Northampton, MA.

https://scholarworks.smith.edu/ant_facpubs/3

This Article has been accepted for inclusion in Anthropology: Faculty Publications by an authorized administrator of Smith ScholarWorks. For more information, please contact scholarworks@smith.edu 


\title{
The Ovicaprine Mystique: Livestock Commodification in Postindustrial
}

\section{$\underline{\text { Lesotho }}$}

\author{
Colin Hoag ${ }^{1,2 *}$ \\ ${ }^{1}$ Department of Anthropology, Smith College, Northampton, MA. \\ ${ }^{2}$ Section for Ecoinformatics and Biodiversity, Department of Bioscience, Aarhus University. \\ *Email: (choag@smith.edu)
}

\begin{abstract}
Economic anthropologists often look to goods that resist commodification to understand how culture determines what can be exchanged and on what terms. Livestock in Africa have served as prominent examples of such "recalcitrant commodities." In this paper, I argue that goods which do not resist commodification - what I call "clean-break commodities"also illuminate the culture of the economy. Drawing on 15 months of fieldwork in Lesotho, I contrast the reticence to sell cattle in African societies, long the focus of anthropologists as well as experts in conservation and development, with the prodigious sale of sheep and goats (i.e., ovicaprids). Focus on charismatic cattle cultures obscures both the historically shifting commodification of ovicaprids, and the economic dreamworlds in which they are enrolled. Ovicaprid cultures have morphed as rural Basotho navigated structural transitions in the regional political economy—from recently colonized ethnostate, to labor reserve for South African mining industries, to defunct labor reserve. Just as the resistance of cattle to commodification described by Ferguson as the "bovine mystique" opened a window into social life in the labor reserve, I suggest the facile commodification of ovicaprids that I call the "ovicaprine mystique" does the same for the postindustrial period.
\end{abstract}


Keywords: Bovine mystique; livestock; postindustry; commodification; Sub-Saharan Africa. 
An older man, perhaps in his sixties, appeared in the doorway of the village court, cutting a silhouette in the bright morning sunlight that poured into the room. As per custom, he leaned his herding stick (molamu) against the wall outside and removed his knit hat as he entered. The man greeted the handful of people in the room with a slight bow, a two-handed wave, and a quiet greeting, "Hello everyone" (Lumelang), before sitting next to me. Opening up a black plastic bag he was holding on his wrist, he carefully pulled out three small booklets and a folded piece of paper, which he proceeded to unfold and hand to the chief (morena). The chief and the secretary (mongoli) were seated at the front of the room behind an old, rickety table painted in the turquoise color so often used in Lesotho on doors, window frames, and furniture. It was early in my fieldwork in the rural Lesotho highlands, and I had come to the court to sort through the criticism and praise I had heard about chiefs in their management of grazing land. One of the primary sites where everyday people interact with these figures is the village court, called lekhotla in Sesotho - a place people visit to settle disputes, to obtain the chief's stamp and signatures for official documents, or to register their livestock. I arrived first thing in the morning to see it for myself. But then I got distracted by sheep and goats.

When the man returned to his seat, I asked him why he had come to the lekhotla. He explained that he was selling two sheep. The small booklets that he carried were livestock registration books distributed by the Ministry of Home Affairs that keep an account of his livestock - their type, sex, and markings — with a stamp and signature from his chief. The paper he handed to the chief was a letter written by the man that requested the transfer of title to the buyer, a young local man named Tumisang.

The room slowly filled with people, nearly all of whom did just as this man did: they entered, handed a letter to the chief, and waited. For each case, the chief read the letter and wrote 
up a bewys, an Afrikaans word for the title, or proof of ownership. The bewys listed the name of the seller and buyer and was carbon copied in a government-issued receipt book. The secretary signed the bewys, updated the buyer's and seller's livestock registration books, and had them place their fingerprints on the carbon copy. There were so many people that the chief and the secretary did their work in batches, taking seven to ten receipts and then calling the parties up two by two to have them affix their fingerprints all at once. The sellers included young men and old men-but also several women. This was surprising, given that women are conventionally known to lack access to livestock property, according to the ethnographic record (see Ashton 1967; Ferguson 1994; but see Turkon 2003). The buyers, however, were exclusively men, and mostly young men. I was intrigued. First, given what has been written about the reticence of Basotho (i.e., people from Lesotho) to sell livestock, even during punishing droughts (Ferguson 1994), why were all these livestock being bought and sold? Second, how could these young men, almost none of whom had access to formal employment, be purchasing livestock?

I asked which type of animal people were selling, and invariably it was sheep and goats - mostly sheep. At the end of the day, I asked the secretary how many animals were sold. "Forty-seven," he said. I asked him about how many animals were sold each month, and he did some quick math - they go through about one hundred to two hundred receipts each month on average and each sale includes about one to five animals. He thought about it and told me that he estimates about two hundred to three hundred animals are sold every month — mostly sheep and goats - with perhaps four hundred to five hundred being sold during the months of December and January, when school fees must be paid and when the maize harvest is not yet in, as well as April and May, when the animals are fat and fetch a good price. I asked him how these young men could afford the livestock, and he explained that most would not keep the animals. Instead, 
they would take them in the next few weeks over the border to Qwa-Qwa, the former "Bantustan" or "ethnic homeland" that formed part of apartheid's system of segregation until South African independence, where the livestock would be sold to butcheries. I asked if they were selling the old livestock (maqheku), which Ferguson described as being saleable. No, he said, the livestock being sold are younger animals that will be desirable to butchers. This economic traffic seemed uncanny in rural Mofolaneng, a mountain village that was home to just a few thousand people. It's not only men from Mofolaneng who are trekking these animals to Qwa-Qwa, he added, but from towns all over the northeast highlands. He and I agreed that there must be well over a thousand animals sold in Qwa-Qwa every month.

Much anthropological literature on commodification of the past several decades (Comaroff and Comaroff 1990; Constable 2009; Sharp 2000; Strang 2004) has anchored itself in "recalcitrant commodities"- those goods that resist commodification due to their importance to biological or social life. Think water, land, labor, or intimacy. Anthropologists have shown how the social and material entanglements of these goods interrupt capitalist processes of alienation and, therefore, shed light on the rules that govern different social worlds. Yet, whether goods are resistant to alienation or not, commodification is a social practice (Appel 2012). Indeed, as the substantivist tradition in economic anthropology has shown (see Appadurai 1986), markets are always inflected by gender, kinship, and power-historically and culturally specific, shot through with dreams and nightmares as much as logics and strategies (see, for example, Browne 2009; Jeske 2016; Kaplan 2007; Taussig 1980; Tsing 2015). More than disabusing the distinction between precapitalist and capitalist economies, anthropologists must account for the varied sociality of different kinds of capitalist goods. Recalcitrant commodities may put social formations into sharp relief. But pliable ones are equally sites of struggle and symbolism. 
In this article, I argue for anthropological attention to what I call "clean-break commodities"- those goods that present few barriers to sale. Focusing on the brisk production and sale of ovicaprids (i.e., sheep and goats, sometimes referred to collectively as "small stock") in the southern African country of Lesotho, I aim to show how such clean-break commodities speak to the conceptual and material infrastructures that make commodification possible, including economic dreamworlds, capitalist networks, and even structural violence. Even when commodification appears effortless, I argue, it is a contingent achievement, requiring both agency and specific political, environmental, and symbolic conditions.

Cattle in Africa have served as signature examples of recalcitrant commodities. Since Melville Herskovits (1926) described the "cattle complex" in eastern and southern Africa, anthropologists have drawn attention to cattle's imbrication in a variety of social institutions, including religion, politics, economy, and more (e.g., Comaroff and Comaroff 1990; EvansPritchard 1940). This imbrication complicates their rendering as straightforward, capitalist commodities for market exchange (Ferguson 1994; Hutchinson 1996; also see Gudeman 1986; Murray 1981; Piot 1991), making cattle a key site for understanding social and symbolic systems, particularly as relationships to cattle are reworked by shifting political economies (Jeske 2016; Turkon 2003; White 2015, 2017). It is not only anthropologists who have been captivated by the charisma of noncapitalist, cattle-mediated social relations in Africa, but also conservation and development experts. Based on the notion that cattle confer social status upon their owners, these experts often argue that African people seek to establish unsustainably large herds, causing land degradation (see examples in Anderson 1993; Brockington and Homewood 2001). In Lesotho, for example, experts have sought to promote a beef-production industry for export that might contain land degradation through the force of the "invisible hand" by 
encouraging livestock owners to engage with capitalist markets and sell off their herd when forage is unavailable (Ferguson 1994; World Bank 2010). Anthropologists have done much to expose the essentializing, culturalist fallacies of this view of African cattle. However, they have historically shared with conservation and development workers an overly narrow attention to that single, charismatic livestock category, overlooking the charisma of readily commodified ovicaprids.

My conclusions are based on fifteen months of fieldwork conducted mostly during 2014 in the rural mountain areas of Mokhotlong District, where I interviewed, observed, and interacted with herders, livestock owners, and conservation workers. In the pages below, I argue that sheep and goats deserve scrutiny as rich sociocultural goods - not because of their resistance to commodification, but because of the ease with which they are commodified. Moving historically across distinct periods in the livestock cultures of rural Basotho, my argument is two-fold. First, despite accounts of African reticence to engage capitalist livestock markets, Basotho have long done so with alacrity (Quinlan 1995; Turkon 2003). In Lesotho, sheep and goats have been produced in huge numbers for the better part of a century — specifically, for their wool and mohair sold in global textile markets. Owing to the ingenuity and entrepreneurialism of Basotho, sheep and goats have repeatedly been used as a means of making a living "in the seams" (Tsing 2015) of oppressive governments and structural violence. Ovicaprid production in Lesotho first expanded in the late nineteenth century when commoner Basotho sought to colonize the country's upper highlands and wrest themselves from the control of the chieftaincy (Kimble 1999). Over time, as Lesotho was marginalized and transformed from an agricultural center to a labor reserve for South African industry (Murray 1981), sheep and goat production became both a retirement strategy for miners returning from South Africa as well as part of an economic 
dreamworld into which young men and women imagined themselves. They introduced improved breeds into their herds, and Lesotho became a major producer of wool and mohair, second in mohair production today only to South Africa (IFAD 2014). Ironically, whereas development and conservation workers believe that market-based livestock production could alleviate overstocking and land degradation, Basotho eagerness to produce ovicaprids for global markets may itself be the cause of degradation - a product of commodified small stock, not uncommodified cattle. ${ }^{\mathrm{i}}$

My second argument is that while small stock have long been important to Basotho livelihoods, their use is shifting with Lesotho's transformation from labor reserve to defunct labor reserve. With the collapse of mining employment for Lesotho citizens in the late 1980s, the entrepreneurial dream in which ovicaprids figured as a source of retirement income dissolved. Instead, ovicaprids became a full-fledged occupation, increasing the pace with which the animals are raised and sold. By integrating mutton breeds into their herds, rural Basotho are developing dual-purpose animals that can be raised for wool and mohair but also sold at a moment's notice in South African butcheries.

Just as the resistance of cattle to commodification opened a window into social life in the labor reserve (Ferguson 1994), I suggest the facile commodification of ovicaprids does the same. If the "bovine mystique" (Ferguson 1994) described a set of cultural rules and political contexts that puzzlingly circumscribed the sale of cattle, what I call the "ovicaprine mystique" describes a set of conditions that have enabled a puzzlingly vigorous production and exchange of small stock. Whether partially commodified, as in the case of cattle, or fully commodified, as the case of sheep and goats, commodities are always textured by their dynamic cultural particularity. Rather than providing a reassessment of the status of the bovine mystique in contemporary 
Lesotho (see Turkon 2003), I provide an account of the ovicaprine mystique and how it has changed historically. What has remained the same over time, however, has been the danger and precarity of Lesotho's structurally unequal arrangement with South Africa. Like the danger of life on the mines, transporting ovicaprids illegally across the border to butcheries is a risky proposition. In the rubble of old arrangements, new and still-precarious opportunities are forged.

The fluid nature of the commodity relations rural Basotho have with ovicaprids - the historicity of these differently commodifiable livestock - points to the fact that commodity status is not binary but rather dynamic. It suggests that charismatic, recalcitrant commodities do not show us the ultimate limits of commodification but rather expose that unique set of conditions necessary to any act of commodification. As commodities-in-the-making, sheep and goats enable people to imagine themselves as figuring into an emergent economy. Their manipulation is not merely about kin and symbolic relations but has to do with navigating broader processes of status mobility through strategic buying, selling, and breeding. This is not necessarily utilitarian, rational economic action, however, as status is inherently a social and cultural construction. Small stock are enrolled as intimate figures in the economic dreamworlds of Basotho eager to find a future in post-labor reserve Lesotho.

\section{CULTURES OF COMMODIFICATION}

In the anthropological literature on commodification, there has been a tendency to focus on those commodities that resist commodification. Reminiscent of Karl Polanyi’s ([1944] 2001) influential discussion of "fictitious commodities"-labor, land, and money—which he said were not produced per se but rather socially imagined and institutionally safeguarded as such, 
anthropologists show that commodification is not as straightforward and universal as economists might have us believe. Instead, it is culturally specific. In an earlier mode, this literature explored "spheres of exchange" and other cultural rules that govern what can be exchanged, with whom, and when, in marked contrast to market economies (Bohannan 1955; Gudeman 1986; Piot 1991). More recently, scholars have explored recalcitrant commodities through an exploration of the commodification-of-everything spirit of neoliberalism, including the commodification of language (Heller 2010), nature (Büscher, Dressler, and Fletcher 2014), scholarship and higher education (Wright 2017), water (Strang 2004), human organs (Sharp 2000), and intimacy (Constable 2009). This literature emphasizes that where recalcitrant commodities are pushed into commodification, contradictions arise that must be resolved. Studies of cattle ownership in Africa have served as key examples of the embeddedness of goods within a social fabric (EvansPritchard 1940; Herskovits 1926), depicted as a Maussian "total social fact" (Mauss [1925] 2016) and a site for exploring how African societies respond to urbanization and cash economies (Comaroff and Comaroff 1990; Ferguson 1994; Hutchinson 1996; Jeske 2016; Murray 1981; Turkon 2003; White 2017).

Anthropologists have been less interested in applying this same kind of scrutiny to what I term "clean-break commodities": goods that appear to disarticulate easily from social relations and the conditions of their production. ${ }^{\text {ii }}$ Contrast, for example, the attention given to African cattle with the sparse mention of African sheep and goats. Where small stock are discussed, they tend to figure straightforwardly as elements in a livelihood strategy or system of production (Dahl and Hjort 1976; Orlove 1977; but see Turkon 2003), rather than a rich cultural domain, as with cattle. This risks forgetting a lesson from the substantivist-formalist debates of the 1970s and 1980s (see Appadurai 1986) — that economics is not a domain of rational actors but rather of 
cultural, historical actors - by assuming that some commodities are more inflected by culture than others. The disenchanted commodity was never that. The commodity is, after all, as Marx ([1867] 1990, 163) said, "a very queer thing, abounding in metaphysical subtleties and theological niceties." Beyond a crass delineation between the status of goods under precapitalism and capitalism, we need a more nuanced sense of the commodity's functional traits and conditions of possibility.

What is it that makes ovicaprids saleable? Commodification is historically contingent, so before looking at the ovicaprine mystique in depth, we need to know more about its origins and permutations. In the next section, I provide a historical overview of livestock production in the highlands - its timing and motivations — over three distinct phases. In the subsequent section, I describe how rural Basotho appreciate the value of different livestock types during the labormigration era and today. Finally, through the stories of livestock owners producing and selling sheep and goats in South African butcheries, I show how a new economy of meat production is becoming formalized.

\section{SHEEP, GOATS, AND THE SETTLING OF THE LESOTHO HIGHLANDS}

\section{Phase I: 1700-1900}

Sheep and goats - but especially sheep — have been central figures in the settlement and colonization of southern Africa. This is true over the longue duree in that ovicaprids enabled the southward colonization of pastoralist people in Africa by "domesticating" the landscape in tsetse zones through the clearing of woody vegetation (Gifford-Gonzalez and Hanotte 2011). For example, fat-tailed sheep were present in indigenous Khoisan herds when the Portuguese and 
Dutch first came to southern Africa in the fifteenth century (Gifford-Gonzalez and Hanotte 2011). But it is also true for the colonial period. William Beinart (2003) describes the dramatic increase of these animals in South Africa during the eighteenth and nineteenth centuries. Sheep numbered about 1.5 million in the cape [THE WORD "CAPE” SHOULD REMAIN IN CAPS BECAUSE IT REFERS TO A PROPER NOUN-IT IS THE USAGE FOR REFERRING TO A REGION OF SOUTH AFRICA, PREVIOUSLY KNOWN AS THE CAPE COLONY AND

\section{LATER THE CAPE PROVINCE AND WESTERN CAPE. IT IS COMMONLY}

CAPITALIZED WHEN REFERRED TO IN REGIONAL WRITTEN DISCOURSE.] in 1806, though they were mostly the fat-tailed mutton breeds. Wool-producing merino sheep subsequently rose in importance, and their population shot up to five million by 1855 and ten million by 1875 as the textile industry in Britain drove significant demand (Beinart 2003, 9). This trajectory mimicked Basutoland's (renamed Lesotho at independence), though merino sheep arrived there several decades later.

Until the 1870s, all livestock types in Basutoland were primarily kept in the lowland areas near villages, with very few kept at "cattle posts"'iii in the colder, expansive highlands. The highlands up to that time were inhabited only by diffuse, highly mobile, and often culturally creolized communities (incorporating San hunger-gatherers), many of whom were involved in or suspected of raiding cattle from lowland communities (Conz 2017; King and Challis 2017). Three factors changed that: land pressure in the lowlands, British colonialism, and class dynamics within Basotho society. Land pressure increased with substantial population growth, loss of lowland Basutoland territory to Afrikaner farmers over the eastern border, and the South African Land Act of 1913, which pushed South African Basotho into Basutoland. This pressure encouraged livestock owners to establish highland cattle posts, which later morphed into 
permanent villages. Around the turn of the twentieth century, Basotho and the British colonial administration came to recognize that the highlands were some of the best sheep-producing areas in the region, albeit for short summer seasons. The British began promoting wool and mohair production (see Quinlan 1995) through the issuing of licenses to white traders for the establishment of mountain trading posts where wool and mohair could be legally exchanged, and later through the construction of bridle paths to facilitate its transport to markets in South Africa. Judith Kimble (1999, 135-37) reports that between 1893 and 1908, Basutoland wool exports grew by 380 percent in weight and 480 percent in value, increasingly from mountain areas. Mohair exports also ballooned by nearly 3,000 percent in weight and value, though they started from much lower levels. In 1923, a wool export duty was introduced, indicating the importance of that growing industry to colonial profits (Kimble 1999, 116-17), and the Prevention of Scab Act was passed to make dipping compulsory throughout the country (see Conz 2017).

Chiefs sought with difficulty to control highland settlement, as commoner livestock owners established highland cattle posts that helped them circumvent chiefly authority over grazing land. Struggles between those two groups were evident from the early twentieth century onward, for example, in conflicts over people who refused to work in matsema - work parties in service of chiefs' agricultural fields — and were fined by chiefs for doing so. Cattle remained at that time tightly tied to the "tributary mode of production" (Kimble 1999) whereby subjects are promised security and prosperity in return for tribute payments of cattle and labor to the chief. Small stock, however, were not under such tight control. Because they could remain for much of the year in the higher, colder reaches of the mountains, they did not conflict with chief-controlled cattle pastures in the lowlands or the lower-lying areas of the highlands. 


\section{Phase II: 1900-1985}

Commoner Basotho exploited that opportunity, and numbers of small stock in Lesotho surged from 1.5 million in 1900 to three million in 1930 (Swallow and Brokken 1986). Significant anxiety emerged at that time surrounding the ecological effects of sheep in both countries, including claims that they were leading to shifts in vegetation, soil erosion and compaction, and even that they were encouraging desiccation - a decrease in rainfall and in the capacity of soils to retain moisture (Beinart 2003; Conz 2017; Driver 1999). After dramatic droughts in the early 1930s, when all livestock types plummeted, herds recovered over the next decade, and highland cattle posts rose "exponentially" between the 1930s and 1980s (Nüsser 2002).

Over time, sheep and goat production became central to rural livelihoods, and Basotho have become skillful fiber producers. However, Basotho had not always been interested in wooland mohair-producing varieties. In the 1830s, when the missionary Thomas Arbousset accompanied King Moshoeshoe to his cattle post in the highlands, Arbousset described indigenous fat-tailed breeds being given preference over European wool breeds, the former of which he saw taken into a covered kraal during inclement weather and fed hand-picked forage (Arbousset [1840] 1991, 78). But by the 1940s, the anthropologist Hugh Ashton (1967) reported that Basotho were more interested in improved sheep and goat varieties than improved cattle. This he ascribed to the heightened social role played by cattle, in contrast to sheep and goats, from which a "considerable cash income is derived from the export of wool and mohair" (140). By the time Ashton was writing in the 1960s, the poor-quality fleeces of earlier times had been "almost completely submerged through the introduction of merino sheep and angora goats" (134). 
The upswing in small-stock production and the transition from fat-tailed mutton to merino wool and angora mohair varieties was a contingent one, owing to specific historical circumstances. Whereas Basutoland in the late nineteenth century was dubbed "the granary of the Free State" (Murray 1981) for its prodigious agricultural production, it would be slowly drawn into becoming a labor reserve for the mining industry through colonial and South African policies. At any given moment since the early twentieth century, tens of thousands of Basotho miners worked in South Africa, returning to Lesotho after retirement or injury. Though Basotho were described in development literature as "subsistence farmers," agriculture was not a primary source of livelihoods but rather one that supplemented the mining wages sent by family members working abroad (Ferguson 1994; Murray 1981).

Class and other social relations in Lesotho were deeply inscribed with this historical process. Because of apartheid-era laws prohibiting miners' families from immigrating to South Africa, and partly because of Basotho desires to remain in their own country, mining labor was in some sense an entrepreneurial activity: a means of acquiring money to invest in a future by varied means, including through bridewealth payments, education for children, a sturdy home, a taxi or clothing business - and a herd of animals. The herd would pay out over time, with cattle producing milk and plow, and sheep and goats producing wool and mohair for slaughter and cash. It is no stretch to suggest that the commodification of small stock acted as a buffer to the monetization of cattle during the labor-reserve era, injecting much-needed cash into rural households where the social ties that prevented cattle sale continued to matter a great deal. That is, the hypercommodification of small stock I call "the ovicaprine mystique" made the bovine mystique possible. 


\section{Phase III: 1985-Present}

Beginning in the mid- to late 1980s, however, this economic dreamworld was no longer tenable. As South Africa transitioned to democracy, opportunities for foreigners in the mines dwindled. The mines mechanized, gold prices plummeted, and jobs were slashed. Lesotho's labormigration economy collapsed (Ferguson 2006). During the height of the labor-migration era, between 1976 and 1986, nearly half of all working-age citizens of Lesotho were absent as migrants. Basotho men working in South African mines dropped from nearly 100,000 in 1990 to 46,000 in 2010 (Crush 2010). It had long been clear that Lesotho only possessed a modicum of sovereignty, given its profound economic dependence on South Africa (Coplan 2001), but Lesotho's transition from labor reserve to defunct labor reserve disabused any lingering doubts. Indeed, Lesotho bears an uncanny resemblance to the apartheid Bantustans in its ethnolinguistic homogeneity and its relation of "disjunctive inclusion" (Mbembe 2008; see also Wolpe 1972) to South African industrial and commercial centers (Ferguson 2006). Lesotho's border with South Africa has been described as a "politically and economically convenient fiction" (Coplan 2001, 115), stemming the flow of people into South Africa while creating market opportunities for illicit goods, such as weapons, marijuana, alcohol, and stolen livestock — dating at least to 1871, when the cape [AGAIN, CAPE SHOULD REMAIN IN CAPS AS DESCRIBED IN MY EARLIER COMMENT] colonial administration annexed Basutoland (Kynoch and Ulicki 2000). But unlike the Bantustans, as Ferguson (2006) has shown, Lesotho is a "real country" and was not dissolved after the end of apartheid. Instead, it was reaffirmed as existing outside the South African body politic.

In rural Lesotho, as in former Bantustans, the further monetization of rural economies, the HIV/AIDS pandemic, and enduring poverty have ramified in people's relationships to 
gender, kinship, livestock, and political authority, in many ways sharpening class and gender identities (Block 2014; Turkon 2003; White 2015, 2017). In the post-labor reserve era, raising sheep and goats has gone from a retirement activity to an occupation. In one of the rare successes of foreign and domestic development work, wool and mohair growers associations were created across the country that organized production, further improved animal breeds for wool and mohair quality, and cut out middlemen to secure favorable prices for farmers' clip. In 2001, they were federated as the Lesotho National Wool and Mohair Growers Association (LNWMGA). Revenues from mohair and wool production in 2016-2017 reached M500 million (USD40 million) (Informative News 2017), a form of foreign revenue that primarily accrues to ordinary people. ${ }^{\text {iv }}$ Tregurtha (2005) states that the average herd size in the mountains is fifty, but that 50 percent of owners own less than forty head of small stock, meaning that much of the production is by smallholders. Figure 1 depicts two smallholder farmers having their sheep shorn at a LNWMGA-affiliated woolshed. 


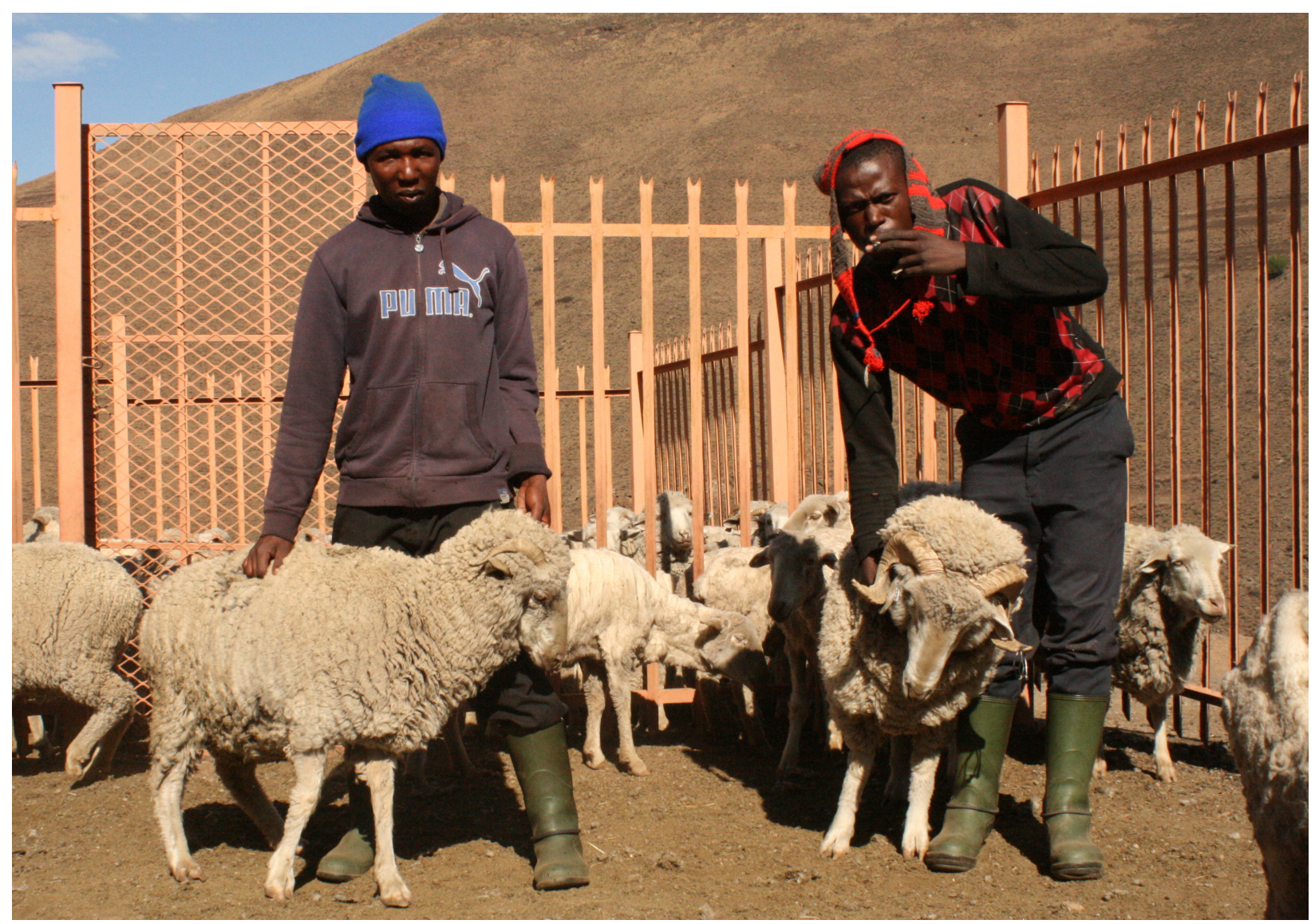

Figure 1. Sheep owners at the woolshed. (Photograph by author)

However, as I began to see at the village court described at the opening of this essay, rural Basotho are seeking new forms of entrepreneurial diversification. While wool and mohair continue to be produced, a new market has been found for mutton, allowing for the quick sale of small stock to young men who traffic them illicitly over the border to South Africa. After my visit to the village court, I asked the secretary whether this was a recent phenomenon. He told me that for a long time - fifty years or more — people from Mokhotlong had been taking wool to Qwa-Qwa for sale, but not the animals themselves. In fact, in the 1950s, there was a woolshed at Letšeng on the high plateau, along the road from Mokhotlong to the lowlands, sited specifically so that animals could be shorn near their cattle posts and their wool taken immediately to QwaQwa by horse or donkey. When did he see sales in sheep and goats increase? It began in the late 
1980s, he explained, because of "the changes" (liphethoho). He said that at that time people at the mines were losing their jobs and they began to think about how else they could feed their families. "They asked themselves, "What am I going to do?"' So, they started to sell animals at butcheries in Qwa-Qwa, where the animals fetched a high price.

Lesotho's structural position vis-à-vis South Africa has shaped the ways that rural Basotho relate to livestock, including both cattle that resist commodification and ovicaprids that do not. This is consistent with other ethnographic literature on Basotho social relations in the wake of shifting political economies (Turkon 2003). Small stock are objects both of longstanding interest (see Figure 2) and of recent innovation in Lesotho, becoming different kinds of commodities at different historical moments. In the following section, I give a fuller account of the ovicaprine mystique and its relationship to the bovine mystique from the perspective of livestock owners.

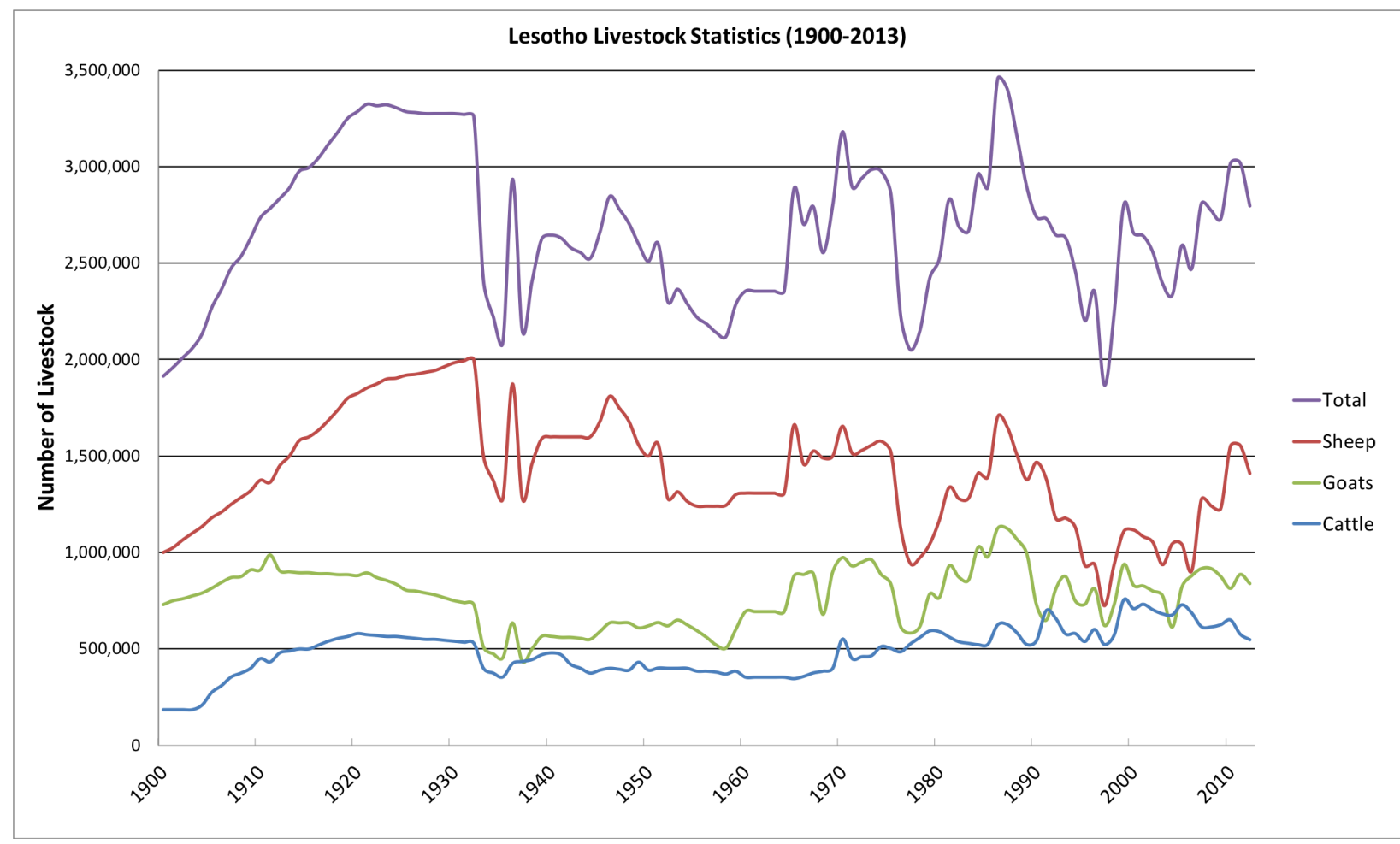


FIGURE 2. Livestock statistics for Lesotho (1900-2013). (Courtesy of Lesotho Bureau of Statistics; Swallow and Brokken 1987)

\section{THE OVICAPRINE MYSTIQUE}

James Ferguson (1994) debunked the perception among conservation and development experts that cattle were an "obsession" of Basotho seeking social status - an obsession experts said led to unsustainably large herds and land degradation — showing instead that cattle ownership needed to be understood with reference to kinship and political economy. Development workers were right, Ferguson explained, that cattle were not treated like an ordinary commodity. They were only commodified according to cultural rules that produced a one-way barrier to sale, what he called the "mystique": cattle could be bought, but not sold. But rather than being holdovers from a timeless precolonial past, the rules that governed cattle exchange reflected the gendered and generational politics of the contemporary labor-migration economy. By investing their wages in cattle, men working in the mines prevented their wives from using the cash on household items, as women were prevented by custom from selling cattle. Similar contests across lines of class and generation operated upon cattle as well. When a development project sought to establish a beef-production industry in the rural areas where many of Lesotho's livestock are located, the effort failed because it misunderstood cattle's position within society (Ferguson 1994).

In a footnote, Ferguson $(1994,297 f)$ suggested that all grazing domestic animals were probably governed by similar rules of exchange as cattle, although he conceded that more research on the point was needed. As a result, he used the term "livestock" to refer to all grazing stock types. But including sheep and goats in this category of "livestock" obscures important 
differences. This is especially so because these differences may have amplified since Ferguson wrote his piece (Turkon 2003). For example, sheep and goats can be sold much more easily than cattle, making them desirable, as I was consistently told. Herders who work for one year herding someone else's livestock are typically paid either twelve small stock or one cow. I would often ask herders whether they preferred to be paid in sheep and goats or in cattle. Without exception, I was told sheep and goats. When asked why, they responded like a young man named Likhang did. "Sheep? They're money" (Linku? Ke chelete), he said, swiping his fingers over an open palm in the vernacular sign for money. Not only do sheep produce money through wool, but they multiply rapidly. Moreover, he and others explained, cattle are major investments. If you have an emergency, you can sell a sheep or goat—but you cannot sell part of a cow. Thus, in contrast to cattle, with their "barriers to sale" (Ferguson 1994), small stock are always ready for sale. They're not sold carelessly, but are saleable whenever one needs the cash for food, medicines for their animals, school uniforms for their children, or other household items. This held generally, contrary to Turkon's (2003) findings, whether I was speaking with owners of small or large herds, and whether the owners were young or old.

Ferguson described how he presented men with a hypothetical situation: If someone offered them one ox or the cash equivalent, which would they choose? The men always chose cash, which could be converted into cattle, whereas the reverse was not true. If they owned a cow, they would never sell it, even under dire circumstances, because of its potential future value. When I presented men with the same scenario for sheep and goats during research in 2014 and 2016, men largely opted for sheep over cash. As one elderly man put it with an apt regional metaphor, "Sheep are our mines!" (Nku ke maene ea rona!). I posed the scenario to a middleaged man whom I picked up on the high plateau while driving to Mokhotlong. He was not 
particularly interested in livestock and owned just a few sheep and a few cows. He didn't want his children to be barui (wealthy in livestock) either, because he'd rather they go to school than become herders. But when I asked him whether hypothetically he'd choose a sheep or R 750 in cash (the price he quoted me for one sheep), he opted for the sheep because "small stock are a business - you make money off of them." I then asked him the same question about whether he would choose a cow or R 4,000 (the going rate). He reported that he would take the money rather than the cow, but not because he could use the money to buy a cow, as told to Ferguson, but because he wanted an animal that he could sell easily. "A cow is difficult to sell—and it takes a long time to grow." During that time, he said, it might die. Sheep and goats, on the other hand, sell easily. Their facile commodification made them desirable.

When I asked which animals women preferred, they, like the men, told me that the cattle are important for plowing, but that the small stock are important because of their easy commodification and their rapid multiplication. When I asked men about whether they or their wives made decisions about when to sell sheep, most told me it was them — not their wives. But some men explained that they would sell when they understood that their wives needed things around the house. Women I spoke with mostly suggested that they chose to sell sheep and goats in concert with their husbands, although some explained that they were more firmly in control. "No! I tell him [when we need to sell]!” one woman explained. To be sure, sheep, goats, and larger stock are primarily the domain of men in rural Lesotho. Many livestock, particularly the small stock, are kept at distant cattle posts over which women have no direct control. But none of the people I spoke with described a situation for sheep and goats quite like that outlined by Ferguson for cattle - that is, as a special domain of property and a dam against the flow of cash. And because small stock are so easily sold, women are certainly able to make more claims upon 
them. In my visits to the lekhotla, I saw numerous women selling small stock themselves. I was told by men and women, in fact, that it had long been the case that men working in South Africa would sometimes instruct the chief of their village to allow their wife to sell sheep as she saw fit. I could not discern how this may have changed with the decline of mining employment, but it seems clear that women have long had greater access to ovicaprids than cattle.

Perhaps more striking to me than the fact that people liked the flexibility of small stock was how confident they were that a market for ovicaprids existed. After all, just as they told Ferguson, conservation workers told me that a big problem facing livestock owners was poor market access. Livestock owners were insistent to me that they could sell ovicaprids anytime they wanted. As indicated above, conservation and development workers described by Ferguson sought to resolve Lesotho's land-degradation problems through the development of a beefproduction industry. They believed that rangeland degradation — seen as pervasive and potentially catastrophic - could only be resolved by extricating cattle from the chains of cultural tradition and social status and placing them under the control of the "invisible hand" of the market. This notion endures today. A World Bank report on Lesotho from 2010, for example, advocated, "Livestock development projects involving pricing policies, trek route construction, new slaughter facilities, [and the] purchasing of livestock in the field [for] reduced numbers of livestock on the range and reduced grazing pressure" (44). It explained that Lesotho should enter into "international trade agreements such as the Lome IV Convention ('Beef Protocol Agreement') which allows for sales of beef to the European Union at above world market levels" (44). In my conversations with government and conservation officials in Lesotho, too, the issue of Basotho valuing cattle for their conferral of social status came up on numerous occasions when I asked them if and why they thought rangelands were degraded. Conservation workers 
believed that livestock owners cared more about the size of their herd than they did about the quality of the animals.

For everyday people, too, the restrictions on the sale of cattle described by Ferguson endure. Rural livestock owners with whom I spoke reported a similar reticence to sell cattle, citing the importance of cattle for bridewealth payments, slaughter at funerals and weddings, or

plowing. Small stock can also be used in certain ritual practices. For example, my ethnographic informants noted that sheep might be slaughtered to welcome a newly married woman to her new village. Sheep (and less commonly, goats) might also be slaughtered at funerals or weddings, particularly if a family is not wealthy enough to slaughter a head of cattle. Nevertheless, I saw no general reticence among rural Basotho to sell small stock on capitalist markets. They have long engaged in such trade and continue to find new ways to do so.

The fact that ovicaprids can be sold easily, however, does not mean that small-stock entrepreneurialism is as desirable as, say, a living wage. The mining economy was one fraught with risk and violence - from thieves in South Africa's cities to the dangers of working underground - and so is the one emerging today. In the following section, I describe a novel economy of hybrid small-stock production for both fiber and meat as it appears in living color, characterized like the migrant-labor economy by danger, precarity, and masculinity (see Coplan 1994).

\section{JOURNEYS TO QWA-QWA}

Thapelo and his friend Khutliso were heading to a horse race that Thapelo's uncle would be participating in, and they invited me along. On our way there, Thapelo told me that he planned to 
head to Qwa-Qwa the following morning, taking twelve sheep with him. What Thapelo referred to as "Qwa-Qwa" technically does not exist. That is the name of the apartheid Bantustan created on Lesotho's northern border, an impoverished "ethnic homeland" that was designated for South African Basotho who were not in possession of a permit to work in that country's segregated white cities and towns. Qwa-Qwa was dissolved as a legal entity with the end of apartheid, but it remains a poor and densely populated area featuring a large town, Phuthaditjhaba. With a population of 55,000 people, Phuthaditjhaba is, like other former Bantustan capitals, a conspicuous urban center in the middle of an otherwise rural landscape. Most of the land surrounding it, however, belongs not to smallholders but to large agricultural companies or individuals. Few of those enterprises raise meat for the town's butcheries, meaning a market opportunity exists for people like Thapelo. He can sell his small stock there for around twice the going rate in Lesotho. (Sheep are mostly desired in Qwa-Qwa, but further to the east, where amaZulu people predominate, goat meat is preferred.)

Like those purchasing livestock at the lekhotla I described at the beginning of this essay, many young men in the Mokhotlong area make a living in this way, buying animals with whatever money they have or can borrow and selling them in Qwa-Qwa. But it is no easy task. The trip there is arduous and dangerous. After paying a truck to drop him and his animals off on the high plateau along the road between Mokhotlong and Butha-Buthe, Thapelo will set out at a quick pace north. From noon, when he begins the hike, he will drive the animals through the day and through the night, arriving before dawn at the edge of the escarpment that marks the border with South Africa. From there, he will descend about four thousand feet into Phuthaditjhaba, whose nighttime lights illuminate the trail. There is a border gate along the footpath and $4 \times 4$ road at the base of the mountains, which Thapelo will need to avoid; like most other herders, neither 
Thapelo nor his animals have the proper documents to enter South Africa, which are difficult and expensive to acquire. Over the course of the next few days, he will stay with friends and bring his animals to one of the main kraals in the town, where buyers from local butcheries come. When all or most of his sheep have been sold, he will return home by the same path, cash in hand.

Thapelo explained this all with an air of satisfaction — a kind of masculine pride. With a wife and a young baby, he was eager to reinvest his profits in more sheep that he can sell in Qwa-Qwa. Thapelo had sought work in South Africa without success and was disinclined to continue working at the cattle post as he had for several years prior, given how little herders are paid.

I asked Khutliso if he drove animals to Qwa-Qwa, too. I half suspected not. Whereas Thapelo was stocky and confident, Khutliso had a small frame and disarmingly kind eyes. He used to do it, he told me, flashing a nervous smile and bowing his head down. But he doesn't anymore. He explained on my prodding that, after having made the trip a few times, he had a bad experience. Three years ago, he and his childhood friend Relebohile were held up at gunpoint and robbed of their entire flock - about thirty animals. Two armed men stopped them at daybreak, just as they reached the escarpment. Worried that he and Relebohile would head to the police after having seen their faces, the two men took Khutliso and Relebohile to a cove, beat them up, and tied them together. After several hours, during which time Khutliso assumed they were trying to make a plan, the men decided to shoot them. With Khutliso watching, the men put the gun to Relebohile's head and pulled the trigger — the gun jammed. They stabbed Khutliso in the stomach, immobilizing him, and then stabbed his friend repeatedly. Khutliso pulled up his shirt and showed me a one-inch scar on the side of his abdomen. While the men prepared a fire 
that Khutliso believed would be used to burn the bodies, Khutliso managed to free himself of the rope around his hands and feet. He ran away, hobbling with his stomach wound as fast as he could back to the road through the day and into the night. There, he managed to catch a lift with a passing car back to the clinic at Mapholaneng. He will never take animals to Qwa-Qwa again, he told me.

Shocked by the sadness and violence of the story, I asked Thapelo if he wasn't scared about his impending trip. He replied, "It's just that the money bites, it bites" (Feela he chelete ea loma, ea loma).

\section{LEKALAPENSE: WEIGHING WOOL AND MUTTON}

An emphasis on the importance of wool production in Lesotho over the second half of the twentieth century by British colonists, rural Basotho, and the Lesotho National Wool and Mohair Growers Association (LNWMGA) has promoted wool-producing breeds of sheep. Consider the use of the term lekalapense in Sesotho. The term is a Sesotho-fied version of the Afrikaans word, kaalpens, which means bare (kaal) stomach (pens), or "no wool on the stomach." The term refers to the Dohne Merino sheep, a type of merino from Germany with a wide, short tail, produced for its meat instead of its wool. However, the term is used in a derogatory way to refer to any sheep with poor wool quality by wool farmers and employees at the woolsheds, where sheep and goats are shorn. At LNWMGA woolsheds, it was explained to me that a lekalapense would be expelled because it threatened to diminish the quality of the clip as a whole. A lekalapense, I was told by several livestock owners, is "a bad breed among a good breed." In fact, the word has been recontextualized to apply to people, connoting a polluted, outsider status. In such cases, it is 
extremely derogatory, and one man even told me that "someone would kill you if you called them lekalapense."

One evening, as I walked along a road after finishing some interviews with livestock owners, I bumped into a friend of mine - a young and energetic man named Lesuhla. He flagged me down as I walked along the road past his village, eager to show me his new ram. He had told me about it once before, so I was interested to see what he was so excited about. He explained that it was a "German" type, meaning that it is fat, but produces only mediocre wool. A young herder who saw us looking at the animal walked over to get a look. He was clearly impressed, and pulled out a cell phone to snap a photo. Lesuhla was excited about the ram because it embodied a grand plan, which he then described to me in impressive detail.

Lesuhla had thirty-four sheep at the time, he explained, five of which he would take to Qwa-Qwa in the coming week. He planned to mate his ram with the remaining sheep, all of which were wool sheep that produce "medium-fine" grade wool. The offspring would be sheep that produce a lot of wool but which would also get fat and fetch a good price at the butcheries. Standing up and gesturing to the agricultural fields outside his home, he said he planned to plant oats as forage for his sheep. Then he swept his hand over to some more agricultural fields in the distance up the hillside from us. There, he would plant two specific varieties of maize that he would mill for the animals. He would bring back a select group of sheep from the cattle post and fatten them up with the maize before taking them to Qwa-Qwa. In addition, he planned to breed his ram with other people's stock, the privilege for which they would pay him (see Figure 3). He joked that he already had a list of people eager to breed with his lekalapense. He would repeat that cycle and each time reinvest the money to multiply his herd. In the longer term, he hoped to build a brick house and, later, to open up a clothing store in nearby Mapholaneng. 


\section{$<$ INSERT FIGURE 3 HERE >}

Lesuhla talked about these plans with excitement. They were so close at hand that it was clear he thought about them regularly. This is only the tip of the iceberg, he explained. He wanted to increase his production by quite a lot. I asked him if he wasn't scared of the thieves that I had heard about. He nodded his head deeply. One time, his entire herd was stolen by three men armed with guns. He and a friend were making the trip with a herd of ninety sheep when they were stopped. But he seemed pleased that I had asked. He had already agreed with four other men and women to form a kind of cooperative. They would pay annual dues to be members, and these dues would go toward paying the men who herd the animals to Qwa-Qwa, as well as toward purchasing medicines and forage for their animals. Members would be obliged to direct part of their profits toward purchasing more animals, and every time animals were taken to Qwa-Qwa the herd would be comprised of a number of each of their animals. This way, if the animals were lost to theft, the effects on each individual would be minimized.

Lesuhla and his collaborators were refining an approach to the contingent economy of mutton and wool. The lekalapense is just the latest development in a long-standing relationship between Basotho and small stock. Selling these animals in Qwa-Qwa, he and others like him make life possible in postindustrial Lesotho. By developing a line of sheep that produce wool but that are also desirable to butcheries, they both interrupt and extend the government's efforts to capitalize on Lesotho's highland pastures through wool and mohair production. This is not an unambiguously positive development, however. In hedging against the risk and violence of this illicit trade, his venture shows that new livestock entrepreneurship could be as dangerous as life on the mines. 


\section{CONCLUSION}

In their accounts of African livestock use, anthropologists and conservation and development experts have, through their exclusive focus on recalcitrant cattle commodities, obscured the importance of ovicaprids to culture, economy, and ecology. Small stock have grossly outnumbered cattle for decades in Lesotho, partly prompting the settlement of the highlands itself, and enabling rural Basotho to navigate the structural violence of life in a labor reserve and in its aftermath. Though conservation workers proposed that the complete commodification of cattle could help reduce land degradation by the guidance of the market's invisible hand, ovicaprid numbers have been high precisely because they were linked to global textile markets. As with the bovine mystique, the cultural particularity of sheep and goats that determines whether they can be commodified — the ovicaprine mystique- has been misunderstood.

Processes of commodification are always socially inflected, whether the goods in question are resistant to commodification or not. As economic anthropologists have shown, a commodity is not just a thing that is sold; it is an achievement, borne of culturally and historically specific conditions of possibility, including regional political economies, entrepreneurialism, social networks, and dreamworlds. It is for this reason that clean-break commodities should be as interesting to anthropologists as recalcitrant ones, as the former also betray sociocultural forms and shifting power relations. Beyond a distinction between recalcitrant commodities and clean-break commodities, I have shown that the terms of commodification for clean-break commodities can change over time as the social relations and structural conditions that underpin them change. Commodity status is not binary but dynamic. This means that the important questions are not whether a good can or cannot be commodified, 
but rather: How are commodities achieved? What are their specific conceptual and material infrastructures?

Ovicaprids became clean-break commodities because they grow quickly and in marginal areas; because of a historical process through which bridle paths, woolsheds, and breeding practices were established for their production; and because of shifting political-economic conditions that have made demands of entrepreneurial diversification on Basotho to survive. In the process of commodification, Basotho projected themselves into that context as agents, expressing particular kinds of economic fantasy. Their dreams arose in response to the slow violence of decades of political-economic marginalization against which sheep and goats had been a lifeline. Small stock in Lesotho became different kinds of clean-break commodities during different historical moments. Once a means to circumvent chiefs in the early colonial period, they morphed into a slow retirement commodity, ameliorating the punishing conditions of the labor-reserve era and allowing young Basotho to envision themselves as entrepreneurs in a dreamworld of accumulation. In the post-labor reserve era, ovicaprids have transformed again into a primary occupation, a get-rich-quick dream. In each case, Basotho worked within the rubble of old arrangements, creatively refashioning existing practices to make a living in the seams of power. But the smuggling of small stock to butcheries in the former South African Bantustan of Qwa-Qwa is dangerous, illustrating the violence and risk that continue to characterize Basotho relationships with South Africa. Whereas Lesotho was once a reproductive community for mines in South Africa, producing young men for the market, today Basotho produce fiber for the global textiles industry and meat for the South African proletariat. 
Colin Hoag Department of Anthropology, Smith College, Northampton, MA, 01063 USA; choag@smith.edu 


\section{REFERENCES CITED}

Anderson, David. 1993. "Cow Power: Livestock and the Pastoralist in Africa." African Affairs 92 (366): 121-33.

Appadurai, Arjun, ed. 1986. The Social Life of Things: Commodities in Cultural Perspective. Cambridge: Cambridge University Press.

Appel, Hannah. 2012. “Offshore Work: Oil, Modularity, and the How of Capitalism in Equatorial Guinea." American Ethnologist 39 (4): 692-709.

Arbousset, Thomas. (1840) 1991. Missionary Excursions. Morija: Morija Museum \& Archives.

Ashton, Hugh. 1967. The Basuto: A Social Study of Traditional and Modern Lesotho. Oxford: Oxford University Press.

Beinart, William. 2003. The Rise of Conservation in South Africa: Settlers, Livestock, and the Environment 1770-1950. Oxford: Oxford University Press.

Block, Ellen. 2014. "Flexible Kinship: Caring for AIDS Orphans in Rural Lesotho." Journal of the Royal Anthropological Institute 20 (4): 711-27.

Bohannan, Paul. 1955. "Some Principles of Exchange and Investment among the Tiv." American Anthropologist 57 (1): 60-70.

Brockington, Dan, and Katherine Homewood. 2001. "Degradation Debates and Data Deficiencies: The Mkomazi Game Reserve, Tanzania.” Africa 71 (3): 449-80.

Browne, Katherine. 2009. "Economics and Morality: Introduction.” In Economics and Morality: Anthropological Approaches, edited by K. Browne and L. Milgram. 1-40. Lanham, MD: AltaMira. 
Büscher, Bram, Wolfram Heinz Dressler, and Robert Fletcher, eds. 2014. Nature Inc.: Environmental Conservation in the Neoliberal Age. Tucson, AZ: University of Arizona Press.

Chalfin, Brenda. 2004. Shea Butter Republic: State Power, Global Markets, and the Making of an Indigenous Commodity. New York: Routledge.

Comaroff, John L., and Jean Comaroff. 1990. “Goodly Beasts, Beastly Goods: Cattle and Commodities in a South African Context.” American Ethnologist 17 (2): 195-216.

Constable, Nicole. 2009. "The Commodification of Intimacy: Marriage, Sex, and Reproductive Labor.” Annual Review of Anthropology 38:49-64.

Conz, Christopher. 2017. ““Wisdom Does Not Live in One House’: Compiling Environmental Knowledge in Lesotho, Southern Africa, C. 1880-1965.” PhD dissertation, Boston University.

Coplan, David B. 1994. In the Time of Cannibals: The Word Music of South Africa's Basotho Migrants. Chicago: University of Chicago Press.

Coplan, David B. 2001. "A River Runs through It: The Meaning of the Lesotho-Free State Border." African Affairs 100 (398): 81-116.

Crush, Jonathan, ed. 2010. Migration, Remittances and "Development" in Lesotho. Migration Policy Series 52. Pretoria: IDASA.

Dahl, Gudrun, and Anders Hjort. 1976. Having Herds: Pastoral Herd Growth and Household Economy. Stockholm: Dept. of Social Anthropology, University of Stockholm.

Driver, Thackwray. 1999. "Anti-Erosion Policies in the Mountain Areas of Lesotho." Environment and History 5 (1): 1-25. 
Evans-Pritchard, E. E. 1940. The Nuer: A Description of the Modes of Livelihood and Political Institutions of a Nilotic People. Oxford: Oxford University Press.

Ferguson, James. 1994. The Anti-Politics Machine: “Development,” Depoliticization, and Bureaucratic Power in Lesotho. Minneapolis: University of Minnesota Press.

Ferguson, James. 2006. Global Shadows: Africa in the Neoliberal World Order. Durham, NC: Duke University Press.

Gifford-Gonzalez, Diane, and Olivier Hanotte. 2011. "Domesticating Animals in Africa: Implications of Genetic and Archaeological Findings." Journal of World Prehistory 24 (1): $1-23$.

Gudeman, Stephen. 1986. Economics as Culture: Models and Metaphors of Livelihood. London: Routledge.

Heller, Monica. 2010. “The Commodification of Language.” Annual Review of Anthropology 39:101-14.

Herskovits, Melville. 1926. "The Cattle Complex in East Africa.” American Anthropologist 28 (1): $230-72$.

Hutchinson, Sharon. 1996. Nuer Dilemmas: Coping with Money, War, and the State. Berkeley: University of California Press.

Informative News. 2017. "Wool, Mohair Exports Top M500 million.” November 7. Maseru, Lesotho. http://informativenews.co.ls/2017/11/07/wool-mohair-exports-top-m500million/.

Jeske, Christine. 2016. “Are Cars the New Cows? Changing Wealth Goods and Moral Economies in South Africa.” American Anthropologist 118 (3): 483-94. 
Kaplan, Martha. 2007. "Fijian Water in Fiji and New York: Local Politics and a Global Commodity." Cultural Anthropology 22 (4): 685-706.

Kimble, Judith. 1999. Migrant Labour and Colonial Rule in Basutoland, 1890-1930. Grahamstown, South Africa: ISER, Rhodes University.

King, Rachel, and Sam Challis. 2017. "The 'Interior World' of the Nineteenth-Century MalotiDrakensberg Mountains." The Journal of African History 58 (2): 213-37.

Kynoch, Gary, and Theresa Ulicki. 2000. “'It Is Like the Time of Lifaqane': The Impact of Stock Theft and Violence in Southern Lesotho." Journal of Contemporary African Studies 18 (2): 179-206.

Marx, Karl. [1867] 1990. Capital: A Critique of Political Economy. Vol. 1. Translated by Ben Fowkes. New York: Penguin.

Mauss, Marcel. (1925) 2016. The Gift. Edited and translated by Jane I. Guyer. Chicago: HAU Books.

Mbembe, Achille. 2008. "The Aesthetics of Superfluity." In Johannesburg: The Elusive Metropolis, edited by S. Nutall and A. Mbembe. 37-67. Durham, NC: Duke University Press.

Murray, Colin. 1981. Families Divided: The Impact of Migrant Labour in Lesotho. Cambridge: Cambridge University Press.

Nüsser, Marcus. 2002. "Pastoral Utilization and Land Cover Change: A Case Study from the Sanqebethu Valley, Eastern Lesotho.” Erdkunde 56 (2): 207-21.

Orlove, Ben. 1977. Alpacas, Sheep, and Men: The Wool Export Economy and Regional Society of Southern Peru. New York: Academic Press. 
Piot, Charles. 1991. "Of Persons and Things: Some Reflections on African Spheres of Exchange." Man, New Series 26 (3): 405-24.

Polanyi, Karl. (1944) 2001. The Great Transformation: The Political and Economic Origins of Our Time. Boston: Beacon Press.

Quinlan, Tim. 1995. “Grassland Degradation and Livestock Rearing in Lesotho.” Journal of Southern African Studies 21 (2): 491-507.

IFAD. 2014. The Kingdom of Lesotho. Wool and Mohair Promotion Project. Report No. 3549LS. IFAD: Maseru, Lesotho.

Sharp, Lesley. 2000. "The Commodification of the Body and Its Parts.” Annual Review of Anthropology 29:287-328.

Strang, Veronica. 2004. The Meaning of Water. Oxford: Berg.

Swallow, B. M., and R. P. Brokken. 1987. “Cattle Marketing Policy in Lesotho.” Network Paper No. 14. ALPAN. Ethiopia.

Taussig, Michael. 1980. The Devil and Commodity Fetishism in South America. Chapel Hill: University of North Carolina Press.

Tregurtha, Norma. 2005. "Enhancing the Structure and Performance of Value Chains: A Case Study of the Lesotho Wool and Mohair Sector." Sixth Annual Service Markets Seminar, September 2005. The Donor Committee for Enterprise Development: Turin, Italy. (http://www.value-chains.org/dyn/bds/docs/452/Tregurtha.pdf.) Accessed on July $12,2018$.

Tsing, Anna Lowenhaupt. 2013. "Sorting out Commodities: How Capitalist Value Is Made through Gifts." HAU: Journal of Ethnographic Theory 3 (1): 21-43. 
Tsing, Anna Lowenhaupt. 2015. The Mushroom at the End of the World: On the Possibility of Life in Capitalist Ruins. Princeton, NJ: Princeton University Press.

Turkon, David. 2003. "Modernity, Tradition and the Demystification of Cattle in Lesotho." African Studies 62 (2): 147-69.

West, Paige. 2012. From Modern Production to Imagined Primitive: The Social World of Coffee from Papua New Guinea. Durham, NC: Duke University Press.

White, Hylton. 2015. "Custom, Normativity and Authority in South Africa." Journal of Southern African Studies 41 (5): 1005-17.

White, Hylton. 2017. “The Materiality of Marriage Payments.” Anthropology Southern Africa 40 (V1): 297-308.

Wolpe, Harold. 1972. "Capitalism and Cheap Labour-Power in South Africa: From Segregation to Apartheid." Economy and Society 1 (4): 425-56.

World Bank. 2010. Project Performance Assessment Report (Document \#54359). Lesotho Highlands Water Project, Phase 1B, Community Development Support Project. Washington, DC: The World Bank.

Wright, Susan. 2017. “Can the University Be a Livable Institution in the Anthropocene?” In The University as a Critical Institution?, edited by R. Deem and H. Eggins. 17-37. Rotterdam: Sense Publishers. 


\section{NOTES}

Acknowledgments. This research was supported by funding from the Social Sciences Research Council (International Dissertation Research Fellowship); Wenner-Gren Foundation Inc. (Dissertation Fieldwork Grant, with funding from the Osmundsen Initiative); Danish National Research Council (Danmarks Grundforskningsfond); UC Santa Cruz Science and Justice Research Center; and the UC Santa Cruz Center for Tropical Research in Ecology, Agriculture, and Development. This manuscript would not have been possible without the assistance of my interlocutors in Lesotho, whose names have been anonymized here. I am extremely grateful to Deborah Thomas and four anonymous reviewers whose careful and generous readings of my text have improved it considerably. Thanks to those who commented upon the ideas in this manuscript, including attendees at the University of Berne Department of Anthropology Colloquium, Filippo Bertoni, Xan Chacko, Chris Conz, Pierre du Plessis, Jim Ferguson, Natalie Forssman, Corinne Hoag, Katherine Homewood, Pinky Hota, Rachel King, Andrew Mathews, Marcus Nüsser, Spencer Orey, Katy Overstreet, Danilyn Rutherford, Sefiri Seepheephe, Heather Swanson, JensChristian Svenning, Motlatsi Thabane, and Anna Tsing. Remaining errors are my own.

${ }^{\mathrm{i}}$ Livestock registration statistics for the mountain village of Mofolaneng, where I conducted research, certainly reflect an emphasis on small stock. Between 2001-2014, sheep accounted for between 60-70\% of the total herd, with goats accounting for another $20-25 \%$.

${ }^{i i}$ Notable exceptions include West (2012), Chalfin (2004), Tsing (2013), and Appel (2012).

iii "Cattle post" is the vernacular English translation for motebo (pl. metebo), a remote outpost where a variety of livestock types are kept - not simply cattle.

${ }^{\text {iv }}$ Most of the fiber is processed in South Africa and sold to textile companies in other countries, meaning that valueadded manufacturing takes place outside of Lesotho. The iconic wool blankets worn by Basotho, for example, are fabricated mostly in Britain. 